\title{
Opsonic activity of intravenous immunoglobulin preparations against Staphylococcus epidermidis
}

\author{
LA CLARK, CSF EASMON \\ From the Department of Medical Microbiology, Wright-Fleming Institute, St Mary's Hospital Medical School, \\ London
}

SUMmaRY Peritoneal dialysis effluent collected from patients undergoing continuous ambulatory peritoneal dialysis had no opsonic activity against Staphylococcus epidermidis and contained low concentrations of IgG and C3 (roughly equal to those found in $0.5 \%$ normal human serum). An intravenous immunoglobulin preparation that showed no opsonic activity against the same organism, on its own or when added to balanced salt solution or peritoneal dialysis fluid, showed good activity when combined with peritoneal dialysis effluent. This was probably due to the presence of low concentrations of $\mathrm{C} 3$ in the effluent as prior heat inactivation at $56^{\circ} \mathrm{C}$ for 30 minutes eliminated any opsonic activity in the immunoglobulin-dialysis effluent mixture. Examination of a range of immunoglobulin preparations showed that their opsonic activity for $S$ epidermidis in the absence of complement varied considerably. Luminol dependent chemiluminescence was unsatisfactory as a method for detecting complement independent immunoglobulin mediated opsonisation. Intravenous immunoglobulin preparations may be useful in boosting the peritoneal defences of those patients undergoing continuous ambulatory peritoneal dialysis (CAPD) who suffer from repeated intraperitoneal infections.

Peritonitis caused by Staphylococcus epidermidis is a major complication of continuous ambulatory peritoneal dialysis (CAPD). ${ }^{1}$ Persistent or recurrent infection may oblige CAPD to be stopped.

Treatment of peritonitis entails the rapid introduction of large volumes of peritoneal dialysis fluid into the peritoneal cavity. This has been shown to impair phagocytic defences by diluting the amounts of immunoglobulin and complement opsonins. ${ }^{23}$ Keane and Peterson ${ }^{4}$ suggested that peritonitis could be managed by enhancing local phagocytic defences. They showed that the addition of purified immunoglobulin to dialysis fluid or effluent increased the opsonic activity of both against $S$ epidermidis.

Standard immunoglobulin preparations prepared from human plasma by the classical Cohn alcohol fractionation method have good biological activity. They contain mainly IgG with little IgM (or IgA). They also contain polymeric aggregates, however, which make them unsuitable for intravenous administration and probably for intraperitoneal use. Immunoglobulin preparations suitable for intravenous use

Accepted for publication 5 March 1986 have been prepared using enzyme treatment, chemical modification treatment with polyethylene glycol, or alcohol fractionation at $\mathrm{pH} 4 .^{56}$

Several of these preparations are now commercially available. In this study we examined the opsonic activity of a range of these for $S$ epidermidis when added to balanced salt solution, peritoneal dialysis 3 fluid, and peritoneal dialysis effluent. Our observation $\delta$ that most intravenous immunoglobulin preparations produced maximal opsonic effect when combined $\circ$ with the low concentrations of complement present in dialysis effluent was confirmed using $0.5 \%$ normal 0 human serum and antibody free baby rabbit serum as alternative complement sources.

\section{Material and methods}

BACTERIA

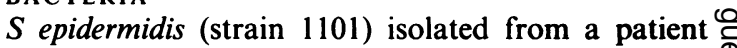

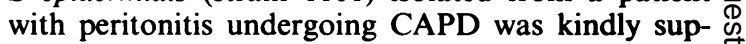
plied by Dr RR Marples, Division of Hospital Infection, Central Public Health Laboratory, Colindale, 0 London. The organism was stored in $20 \%$ glycerol $\vec{D}$ broth in liquid nitrogen and grown overnight at $37^{\circ} \mathrm{C} \stackrel{\frac{1}{\mathbb{2}}}{\circ}$ in brain heart infusion broth (Lab M Ltd). Before use 
Table 1 Immunoglobulin preparations used in study

$\left.\begin{array}{llll}\hline \text { Preparation and batch number } & \text { Code number } & \text { Company } & \text { Method of preparation } \\ \hline \text { Gammaguard 840920 AG11 } & 1 & \text { Travenol } & \text { DEAE Sephadex } \\ \text { Gammaguard 850124 AG11 } & 2 \\ \text { Intraglobin 401034 } & 3 \\ \text { Intraglobin F 41114 } & 4 \\ \text { Intraglobin 401054 } & 5 \\ \text { Intraglobin 402094 } & 6 \\ \text { Intraglobin 401123 } & 7 \\ \text { Gamimune C52401A } & 8 & & \\ \text { Sandoglobulin 40003 } & 9 & \text { DEAE Sephadex } \\ \text { Sandoglobulin 23750670 } & 10 \\ \text { Sandoglobulin 43601010 } & 11 \\ \text { Sandoglobulin 33751391 } & 12 \\ \text { Sandoglobulin 43751070 } & 13 \\ \text { Sandoglobulin 33781490 } & 14\end{array}\right\}$

the bacteria were washed twice in saline $(0.9 \% \mathrm{w} / \mathrm{v})$ and resuspended to a concentration of $3 \times 10^{8}$ colony forming units/ml in Hanks's balanced salt solution without phenol red (HBSS: Gibco Ltd).

\section{OPSONINS}

Pooled normal human serum was collected from six apparently healthy donors and frozen at $-70^{\circ} \mathrm{C}$ in $0.5 \mathrm{ml}$ aliquots. Centrifuged, filtered, peritoneal dialysis effluent from uninfected patients undergoing CAPD was also stored at $-70^{\circ} \mathrm{C}$ in $2 \mathrm{ml}$ aliquots. Table 1 lists the intravenous immunoglobulin preparations used in the study.

\section{POLYMORPHONUCLEAR LEUCOCYTES}

Polymorphonuclear leucocytes were separated from heparinised human venous blood by incubation with half the blood volume of dextran $(6 \% \mathrm{w} / \mathrm{v})$ in saline $(0.9 \% \mathrm{w} / \mathrm{v})$ for 45 minutes. The leucocyte rich plasma layer was removed and centrifuged at low speed. Residual red cells were lysed by treatment for 12 minutes with $10 \mathrm{ml}$ Tris buffered ammonium chloride $(0.83 \% \mathrm{w} / \mathrm{v})$. Cells were washed twice and resuspended to a concentration of $1.5 \times 10^{6} / \mathrm{ml}$ in HBSS supplemented with fetal calf serum $(0 \cdot 1 \% \mathrm{v} / \mathrm{v})$.

\section{OPSONISATION}

$S$ epidermidis $(500 \mu \mathrm{l})$ was opsonised with $0.5 \%$ or $2.5 \%$ normal human serum or $100 \%$ peritoneal dialysis effluent, as well as with the immunoglobulin preparations $(1-10 \mathrm{mg} / \mathrm{ml})$. The reaction mixture was made up to $1 \mathrm{ml}$ with $\mathrm{HBSS}$ and incubated at $37^{\circ} \mathrm{C}$ for 15 minutes. The reaction was stopped by the addition of $1 \mathrm{ml} \mathrm{HBSS}$ at $4^{\circ} \mathrm{C}$. Bacteria were washed twice in phosphate buffered saline and resuspended in HBSS at the original concentration.

\section{PHAGOCYTIC ASSAYS: MICROSCOPY}

Opsonised $S$ epidermidis were diluted $1 / 100$ in HBSS, and $200 \mu \mathrm{l}$ of the suspension were incubated with an equal volume of polymorphonuclear leucocytes at $37^{\circ} \mathrm{C}$ for 15 minutes on a roller. An aliquot $(100 \mu \mathrm{l})$ of this mixture was then cytocentrifuged and the smear fixed in methanol and stained by Giemsa's method. Results were expressed as the percentage of polymorphonuclear leucocytes with ingested bacteria.

\section{LUMINOL DEPENDENT CHEMILUMINESCENCE}

Suspensions of opsonised bacteria $(200 \mu \mathrm{l})$ were added to $500 \mu$ l of polymorphonuclear leucocytes $\left(10^{6} / \mathrm{ml}\right)$ and $900 \mu 10^{5} \mathrm{M}$ luminol (Sigma 6) dissolved in dimethyl sulphoxide, and then diluted in HBSS. The mixture was maintained at $37^{\circ} \mathrm{C}$ in a Driblock 08-3 (Techne). After 15 minutes the mixture was placed in the reaction chamber of a 1250 luminometer (LKB) at $37^{\circ} \mathrm{C}$ and the peak light generated measured in $\mathrm{mV}$ at 15 minutes.

\section{COMPLEMENT AND IgG VALVES}

These were measured on low concentration radial immunodiffusion plates for $\mathrm{C} 3 \mathrm{c}$ and $\mathrm{IgG}$ (Behring).

Table 2 Opsonic activity and concentrations of albumin, $\mathrm{IgG}$, and C3c in peritoneal dialysis effluent from 108 patients without evidence of peritonitis (dwell time $\leqslant$ five hours)

\begin{tabular}{|c|c|c|c|c|c|}
\hline $\begin{array}{l}\text { Opsonin } \\
\text { source }\end{array}$ & $\begin{array}{l}\text { Chemiluminiscence } \\
(m V) \\
\text { Mean }\end{array}$ & $\begin{array}{l}\text { Phagocytosis } \\
\text { (\%) } \\
\text { Mean }\end{array}$ & $\begin{array}{l}\text { Albumin } \\
(m g / d l) \\
\text { Mean concentration }\end{array}$ & $\begin{array}{l}\lg G \\
(m g / d l)\end{array}$ & $\begin{array}{l}C 3 c \\
(\mathrm{mg} / d l)\end{array}$ \\
\hline $\begin{array}{l}2-5 \% \text { pooled normal human serum } \\
\text { Dialysis effluent }\end{array}$ & $\begin{array}{l}12 \\
62 \\
12\end{array}$ & $\begin{array}{l}12 \\
44 \\
12\end{array}$ & $\begin{array}{r}100 \\
44\end{array}$ & $\frac{30}{6-4}$ & $\begin{array}{l}1-4 \\
0-39\end{array}$ \\
\hline
\end{tabular}


Table 3 Effect of addition of pooled normal human serum or intravenous immunoglobulin preparation to Hanks's balanced salt solution or peritoneal dialysis fluid on its capacity to opsonise $S$ epidermidis

\begin{tabular}{|c|c|c|c|}
\hline Medium & Opsonin source (concentration) & $\begin{array}{l}\text { Chemihuminescence }(m V) \\
\text { Mean (SD) }\end{array}$ & $\begin{array}{l}\text { Phagocytosis (\%) } \\
\text { Mean (SD) }\end{array}$ \\
\hline HBSS: & $\begin{array}{l}\text { Normal human serum (2-5\%) } \\
\text { IgG }(1 \mathrm{mg} / \mathrm{ml}) \\
\text { IgG }(5 \mathrm{mg} / \mathrm{ml}) \\
\text { IgG }(10 \mathrm{mg} / \mathrm{ml})\end{array}$ & $\begin{array}{l}12(2) \\
48(6) \\
16(3) \\
17(4) \\
17(4)\end{array}$ & $\begin{array}{l}11(1) \\
49(7) \\
13(1) \\
19(3) \\
25(5)\end{array}$ \\
\hline Dialysis fluid: & $\begin{array}{l}\text { Normal human serum (2-5\%) } \\
\text { IgG }(1 \mathrm{mg} / \mathrm{ml}) \\
\text { IgG }(5 \mathrm{mg} / \mathrm{ml}) \\
\text { IgG }(10 \mathrm{mg} / \mathrm{ml})\end{array}$ & $\begin{array}{l}11(1) \\
52(7) \\
14(3) \\
19(5) \\
17(4)\end{array}$ & $\begin{array}{l}11(1) \\
47(9) \\
15(6) \\
18(9) \\
20(6)\end{array}$ \\
\hline
\end{tabular}

Table 4 Opsonisation of S epidermis by $2.5 \%$ normal human serum and intravenous immunoglobulin preparation (Sandoglobulin) combined with heat inactivated or unheated peritoneal dialysis fluid containing a low concentration of $C 3^{*}$

\begin{tabular}{|c|c|c|}
\hline Opsonin source & Chemiluminescence $(m V)$ & Phagocytosis (\%) \\
\hline $\begin{array}{l}\text { Unopsonised } \\
2.5 \% \mathrm{normal} \text { human serum } \\
1 \mathrm{~g} 10 \mathrm{mg} / \mathrm{ml} \text { and peritoneal dialysis effluent } \\
1 \mathrm{~g} 10 \mathrm{mg} / \mathrm{ml} \text { and heated peritoneal dialysis efiluent } \dagger \\
1 \mathrm{~g} 5 \mathrm{mg} / \mathrm{ml} \text { and peritoneal dialysis efiluent } \\
1 \mathrm{~g} 5 \mathrm{mg} / \mathrm{ml} \text { and heated peritoneal dialysis effluent } \\
1 \mathrm{~g} 1 \mathrm{mg} / \mathrm{ml} \text { and peritoneal dialysis efiluent } \\
1 \mathrm{~g} 1 \mathrm{mg} / \mathrm{ml} \text { and heated peritoneal dialysis efiluent }\end{array}$ & $\begin{array}{l}14 \\
57 \\
53 \\
21 \\
47 \\
17 \\
25 \\
15\end{array}$ & $\begin{array}{l}8 \\
58 \\
64 \\
26 \\
60 \\
18 \\
35 \\
14\end{array}$ \\
\hline
\end{tabular}

* Measured by microscopic phagocytic assay and luminol dependent chemiluminescence.

theated at $56^{\circ} \mathrm{C}$ for 30 minutes.

\section{Results}

Peritoneal dialysis effluent from uninfected patients (dwell time $\leqslant 5$ hours) was unable to opsonise $S$ epidermidis. Concentrations of $\mathrm{IgG}$ and $\mathrm{C} 3$ in the effluent were low, more or less equivalent to those in $0.5 \%$ normal human serum (Table 2). An intravenous immunoglobulin preparation (Sandoglobulin) was used as a source of opsonin. When added to either HBSS or peritoneal dialysis fluid, in concentrations ranging from $1 \mathrm{mg} / \mathrm{ml}$ to $10 \mathrm{mg} / \mathrm{ml}$, it failed to enhance the uptake of $S$ epidermidis in comparison with $2.5 \%$ normal human serum, which gives optimal opsonisation of $S$ epidermidis (Table 3). When added to peritoneal dialysis effluent with a low IgG and C3 content $(5.0 \mathrm{mg} / \mathrm{dl}$ and $0.45 \mathrm{mg} / \mathrm{dl}$, respectively), however, which itself was a poor opsonin, the uptake of $S$ epidermidis was enhanced (Table 4). Heating the effluent at $56^{\circ} \mathrm{C}$ for 30 minutes removed this effect, suggesting that the key factor in the dialysis was the low concentration of $\mathrm{C} 3$ in the unheated effluent, which, together with the added immunoglobulin, provided an effective opsonic mixture.

Table 5 shows the opsonic activity of $14 \mathrm{immu}$ noglobulin preparations, representing four different products, against $S$ epidermidis, compared with that of $2.5 \%$ normal human serum. Two conclusions can be drawn from these results. First, the various preparations differed in their capacity to opsonise $S$ epider- midis in the absence of complement: there was also variation between different batches of the same product. Second, with purified immunoglobulin, luminol dependent chemiluminescence did not seem to be an effective method of monitoring opsonic activity. Even when the microscopic assay showed good bacterial uptake, chemiluminescence remained poor.

The importance of complement for opsonisation was shown by examining the opsonic activity of six immunoglobulin preparations in the presence or: absence of complement, provided either by $0.5 \%$ or

Table 5 Opsonic activity of 14 IgG preparations against $S$ epidermidis

\begin{tabular}{|c|c|c|}
\hline $\begin{array}{l}\text { Immunoglobulin source } \\
\text { (Ig preparations } 5 \mathrm{mg} / \mathrm{ml} \text { ) }\end{array}$ & $\begin{array}{l}\text { Chemihuminescence } \\
(\mathrm{mV})\end{array}$ & $\begin{array}{l}\text { Phagocytosis } \\
(\%)\end{array}$ \\
\hline $\begin{array}{l}- \\
2 \cdot 5 \% \text { (normal human serum) } \\
\text { Ig(1) } \\
\operatorname{Ig}(2) \\
\operatorname{Ig}(3) \\
\operatorname{Ig}(4) \\
\operatorname{Ig}(5) \\
\operatorname{Ig}(6) \\
\operatorname{Ig}(7) \\
\operatorname{Ig}(8) \\
\operatorname{Ig}(9) \\
\operatorname{Ig}(10) \\
\operatorname{Ig}(11) \\
\operatorname{Ig}(12) \\
\operatorname{Ig}(13) \\
\operatorname{Ig}(14)\end{array}$ & $\begin{array}{l}8 \\
45 \\
14 \\
15 \\
12 \\
13 \\
12 \\
14 \\
15 \\
13 \\
12 \\
12 \\
16 \\
16 \\
15 \\
15\end{array}$ & $\begin{array}{l}21 \\
53 \\
53 \\
41 \\
51 \\
26 \\
22 \\
39 \\
35 \\
39 \\
36 \\
33 \\
32 \\
35 \\
26 \\
28\end{array}$ \\
\hline
\end{tabular}


Table 6 Opsonisation of $S$ epidermis by $1 \mathrm{~g}$ preparations $1,2,4,6,8$, and 14 (Table 1 ) with or without $0 \cdot 5 \%$ normal human serum as measured by microscopic phagocytic assay and luminol dependent chemiluminescence

\begin{tabular}{lcc}
\hline Opsonin source & Chemiluminescence $(\boldsymbol{m} V)$ & Phagocytosis (\%) \\
\hline Unopsonised & 8 & 22 \\
Normal human serum 0.5\% & 12 & 22 \\
Normal human serum 2.5\% & 45 & 53 \\
Ig1 & 14 & 53 \\
Ig1 and 0.5\% normal human serum & 33 & 53 \\
Ig2 & 17 & 42 \\
Ig2 and 0.5\% normal human serum & 38 & 68 \\
Ig4 & 15 & 24 \\
Ig4 and 0.5\% normal human serum & 15 & 35 \\
Ig6 & 15 & 35 \\
Ig6 and 0.5\% normal human serum & 15 & 37 \\
Ig8 and 0.5\% normal human serum & 15 & 33 \\
Ig14 & 37 & 49 \\
Ig14 and 0.5\% normal human serum & 17 & 28 \\
\hline
\end{tabular}

Table 7 Opsonisation of $S$ epidermis by $1 \mathrm{~g}$ preparations $1,2,4,6,8$, and 14 (Table 1) with or without peritoneal dialysis effluent or by $0.5 \%$ or $2.5 \%$ normal human serum*

\begin{tabular}{lll}
\hline Opsonin source & Chemiluminescence (mV) & Phagocytosis (\%) \\
\hline Unopsonised & 16 & 16 \\
Normal human serum 0.5\% & 19 & 17 \\
Normal human serum 2.5\% & 69 & 53 \\
Peritoneal dialysis effluent & 18 & 17 \\
Ig1 & 27 & 39 \\
Ig1 and 0.5\% peritoneal dialysis effluent & 66 & 50 \\
Ig2 & 27 & 39 \\
Ig2 and 0.5\% peritoneal dialysis effluent & 68 & 53 \\
Ig4 & 20 & 19 \\
Ig4 and 0.5\% peritoneal dialysis effluent & 20 & 25 \\
Ig6 & 20 & 23 \\
Ig6 and 0.5\% peritoneal dialysis effluent & 20 & 30 \\
Ig8 & 19 & 56 \\
Ig8 and 0.5\% peritoneal dialysis effluent & 52 & 26 \\
Ig14 & 22 & 59 \\
\hline
\end{tabular}

*Measured by microscopic phagocytic assay and luminol dependent chemiluminescence.

$2.5 \%$ normal human serum or peritoneal dialysis effluent, neither of which on their own could opsonise $S$ epidermidis (Tables 6 and 7 ). Similar results were obtained using baby rabbit serum with no detectable antibody to $S$ epidermidis as a complement source (results not shown). Where complement was present the results obtained with chemiluminescence matched those of the microscopic assay.

\section{Discussion}

Peritoneal dialysis effluents from uninfected patients with a dwell time of five and a half hours or less failed to opsonise $S$ epidermidis. These effluents contained low mean concentrations of both IgG and C3, equivalent to those found in $0.5 \%$ normal human serum (a concentration also unable to opsonise $S$ epidermidis). These findings agree with those of Verbrugh et $a l^{2}$ and Keane and Peterson. ${ }^{4}$ Verbrugh et $a l^{2}$ did find some dialysis effluents from uninfected patients that could opsonise staphylococci but these were always associated with longer peritoneal dwell times of between six and 10 hours.

$S$ epidermidis is an organism of low virulence. The course of peritonitis caused by this organism is relatively benign when compared with that caused by other pathogens. The key factors in CAPD $S$ epidermidis peritonitis are firstly the presence of a foreign body, the catheter: this can increase the severity of infection and provides a site on which $S$ epidermidis has been shown to adhere and multiply ${ }^{7}$; second, poor technique or management, or both, resulting in contamination of catheter lumen, connectors, and exit site. Both factors help to provide the high inoculum that is probably necessary for infection with $S$ epidermidis.

We do not yet know the real importance of peritoneal defence mechanisms in determining whether or not infection occurs in particular patients. Keane et $a l^{8}$ found that the incidence of $S$ epidermidis peritonitis was appreciably lower in those patients with a high degree of opsonic activity in their peritoneal dia- 
lysis effluent after overnight exchange. Keane and Peterson ${ }^{4}$ also showed that an immunoglobulin preparation enhanced the uptake of $S$ epidermidis when added either to peritoneal dialysis fluid or effluent, and raised the possibility that passive immunisation of the peritoneal cavity might reduce the incidence of peritonitis in patients undergoing CAPD.

We felt that this observation was worth pursuing more systematically. Given the limitations of standard immunoglobulin preparations for anything other than intramuscular administration, we decided to use intravenous immunoglobulin preparations.

Our initial experiments entailed an intravenous immunoglobulin preparation made by alcohol separation at $\mathrm{pH} 4$ (Sandoglobulin). In contrast to Keane and Peterson, ${ }^{4}$ we found that this showed no opsonic activity against $S$ epidermidis when added to HBSS or dialysis fluid. It had good opsonic activity, however, when combined with dialysis effluent, which itself was not opsonic for the organism. As heat inactivation of the effluent destroyed the opsonic activity of the immunoglobulin-effluent mixture we concluded that opsonisation resulted from a combination of the high IgG concentration and low complement value.

Testing 14 batches of intravenous immunoglobulin, representing four different preparations, showed that two had good opsonic activity against $S$ epidermidis, as measured by a microscopical phagocytic assay, in the absence of complement. When complement was added either as $0.5 \%$ normal human serum or peritoneal dialysis effluent, however, four of six preparations tested were good opsonins: interestingly, luminol dependent chemiluminescence was unsatisfactory as an assay for opsonisation by immunoglobulin alone, the amounts seen being uniformly low. When complement was added chemiluminescence correlated well with the microscopical assay of phagocytosis.

Our results show that intravenous immunoglobulin preparations can enhance phagocytosis in the peritoneal cavity. Batches and preparations will need to be screened for optimal opsonic activity, but their safety remains to be proved and they are expensive. As a result, if any clinical work is to be done we feel that careful patient selection will be vital. The host defence approach to controlling CAPD peritonitis will not reduce the prime importance of good technique and improvements in catheter and connector design. Patients who suffer repeated infections for no apparent reason, however, or in whom we can show opsonic deficiencies in the early phase of peritonitis might be suitable candidates for this approach. We are currently carrying out a prospective study of the opsonic capacity, numbers of phagocytic cells, and values $\mathrm{IgG}$ and $\mathrm{C} 3$ in the dialysis effluents of both uninfected patients on CAPD and those with early peritonitis. This will allow us to see if we can identify groups in whom the use of intraperitoneal immunoglobulin might be helpful.

This work was supported by the National Kidney Research Fund. We thank Drs B Hulme and $\mathbf{R}$ Gabriel for permission to study patients under their care, and both them and all the medical and nursing staff of the Dialysis Unit at St Mary's Hospital for their cooperation.

\section{References}

${ }^{1}$ Spencer RC, Fenton PA. Infective complications of peritoneal dialysis. $J$ Hosp Infect 1984;5:233-40.

${ }^{2}$ Verbrugh HA, Keane WF, Hoidal JR, Freiberg MR, Elliott GR, Peterson PK. Peritoneal macrophages and opsonins: antibacterial defence in patients undergoing chronic peritoneal dialysis. J Infect Dis 1983:147:1018-29.

${ }^{3}$ Clark LA, Easmon CSF. Opsonic requirements of Staphylococcus epidermidis. J Med Microbiol (in press).

${ }^{4}$ Keane WF, Peterson PK. Host defence mechanisms of the peritoneal cavity and continuous ambulatory peritoneal dialysis. Peritoneal Dialysis Bulletin 1984;4:122-7.

${ }^{5}$ Römer J, Morgenthaler J-J, Scherz R, Skvaril F. Characterization of various immunoglobulin preparations for intravenous application I. Protein composition and antibody content. Vox Sang 1981a;42:62-5.

${ }^{6}$ Römer J, Späth PJ, Skvaril F, Nydegger VE. Characterization of various immunoglobulin preparations for intravenous application. II. Complement activation and binding to staphylococcus protein A. Vox Sang 1981b;42:74-8.

${ }^{7}$ Peters G, Locci R, Pulverer G. Adherence and growth of coagulase-negative straphylococci on surfaces of intravenous catheters. $J$ Infect Dis 1982;146:479-82.

${ }^{8}$ Keane WF, Comty CM, Verbrugh HA, Peterson PK. Opsonic deficiency of peritoneal dialysis effluent in continuous ambulatory peritoneal dialysis. Kidney Int 1984;25:539-43.

Requests for reprints to: Professor CSF Easmon, Department of Medical Microbiology, Wright-Fleming Institute, St Mary's Hospital Medical School, London W2 IPG, England. 